\title{
Agrobacterium Mediated Transformation of Tobacco BY2 Cell Suspension with Two Different Zinc Transporters
}

\author{
Zeshan Hassan ${ }^{1,2}$, Paul Bijman ${ }^{1}$, Lotte Woittiez ${ }^{1}$, Azhar Abbas Khan ${ }^{2 *}$, \\ Jawad Munawar Shah ${ }^{2}$, Umbreen Shahzad ${ }^{2}$ \\ ${ }^{1}$ Laboratory of Genetics, Wageningen University and Research Centre, Droevendaalsesteeg 1, 6708 PB, \\ Wageningen, The Netherlands \\ ${ }^{2}$ College of Agriculture, Bahauddin Zakariya University, Bahadur Sub Campus, Layyah, Pakistan \\ Author for correspondence *
}

\begin{abstract}
Zinc is an important micro-nutrient for plant growth and functioning and its homeostasis is a tightly regulated process involving various proteins. NcZNT1 and NcMTP1 proteins naturally occur in Noccaea caerulescens, a zinc-hyperaccumulating plant, which is capable of accumulating extreme zinc-concentrations. We analyzed the zinc-transporting capabilities of these two types of zinc transporters looking at zinc tolerance of tobacco BY2 cells transformed with either of the two transporters. BY2 suspension cells were transformed with NcZNT1 and NcMTP1 by means of agrobacterium-mediated transformation, and cell suspension was then plated on selective medium. After one week, cells were transferred to plates containing different zinc concentrations, and one and a half week later callus development was scored. Callus growth was observed only in the non-transformed control and in the NcMTP1 transformed control on a non-selective plate. On the positive control plates (BY2 transformed with the DsRedencoding construct), no callus was observed and no DsRed expression was seen. Treatment of the cells with agrobacterium appears to have a very devastating effect on cell viability. However, calli may need more development time. It will be possible to determine transformation success and zinc transporter efficacy, based on callus development on plates with different zinc-concentrations.
\end{abstract}

\section{INTRODUCTION}

A small number of plant species has metal hyperaccumulating properties. These plants accumulate metals to a very high level in their shoots, without suffering from toxicity effects (Hassan and Aarts., 2011; Verbruggen et al., 2009). Hyperaccumulating plants are interesting from an environmental point of view, as they may be used for phytoremediation of contaminated soils (Dickinson et al., 2009). One such hyperaccumulator is Noccaea caerulescens, which is capable of accumulating a.o. cadmium and zinc. In 2000, Lasat et al. identified a zinc transporter in $N$. caerulescens which they denoted ZNT1. The $N$. caerulescens ZNT1 gene shows highest homology to Arabidopsis ZIP4 gene, which was discovered by Grotz et al. in 1998. It was further researched and characterized by Hassan (2013), who confirmed the localization of the ZNT1 gene in the plasma membrane while characterized it as a functional $\mathrm{Zn}$ transporter protein. Lasat et al. also analyzed the expression levels of ZNT1, and they found that in $N$. caerulescens, it was continuously expressed at a high level, but in related species such as $T$. arvense, which does not have the Zn hyperaccumulator function, the ZNT1 was expressed at much lower level, unless $\mathrm{Zn}$ deficiency occurred.

Additionally, in 2001, Assunção et al. identified the MTP1 gene, an orthologue of the Arabidopsis AtMTP1 protein which is located in the vacuolar membrane (Hassan., 2013; Desbrosses-Fonrouge et al., 2005). Transport of zinc into the vacuole is an effective way to detoxify the ions. For this reason, AtMTP1 mutants show a hypersensitive reaction to zinc, which confirms the essential role of the AtMTP1 protein in zinc accumulation and detoxification. These findings are further underlined by the results of Hassan., 2013, who concluded that introduction of the ZNT1 or the MTP1 gene in Arabidopsis confers tolerance to zinc stress. This property makes both zinc transporters very interesting topics for further research.

Fast growing cell suspensions of tobacco (Nicotiana tabacum L. cv. BY2), are for a long time in use to study plant physiology and molecular biology (Nagata., 1987). The BY2 cells have a doubling time of 11 hours and can be used for production of recombinant proteins and primary or secondary metabolites (Nagaya et al., 2000). To make a good expression of a foreign gene possible in cultured cells an appropriate promoter and cis-element is necessary (Nagaya et al., 2000). It was shown by An (1985) that a transformation frequency of up to $50 \%$ could be obtained. Success of the transformation was highly dependent on the physiological state of the cells, nature of the Agrobacterium strain used. Highest transformation rates were obtained when using cells in the exponential phase (An., 1985). The present study was aimed at Agrobacterium mediated transformation of Tobacco BY2 cell suspension with $N c Z N T 1$ and NcMTP1 genes to further understand their role in these cells.

\section{MATERIAL \& METHODS}

\section{Experimental set-up}

Transformation was done in Petri dishes on a Whatmann filter paper. After two-three days, agrobacterium was 
washed of and filter papers were transferred to selective agar plates. Six days later, some of the filter papers were transferred to selective plates with different Zincconcentration. For final set-up, see table 1.

\section{BY2 cells}

BY2 suspension cultured cells were obtained from Corrie Hanhart (Wageningen UR). Weekly, $4 \mathrm{ml}$ of cells was subcultured in $40 \mathrm{ml}$ BY2 culture medium (30 g/l saccharose, $4.41 \mathrm{~g} / \mathrm{l} \mathrm{MS}$ Salts (without vitamins, stored at $4^{\circ} \mathrm{C}$ ) (M 0221, Duchefa Biochemie, the Netherlands), 200 $\mathrm{mg} / \mathrm{l} \mathrm{KH}_{2} \mathrm{PO}_{4}, 100 \mathrm{mg} / \mathrm{l}$ myo-inositol, $1 \mathrm{ml} / \mathrm{l}$ Thiamine stock solution (stock $=1 \mathrm{mg} / \mathrm{ml}$ in $\mathrm{H}_{2} \mathrm{O}$, stored at $4^{\circ} \mathrm{C}$ ), 0.2 $\mathrm{ml} / \mathrm{l} 2,4-\mathrm{D}$ stock solution (stock $=1 \mathrm{mg} / \mathrm{ml}$ in $0.1 \mathrm{~N} \mathrm{KOH}$ in $\mathrm{H}_{2} \mathrm{O}$, stored at $4^{\circ} \mathrm{C}$ )) in $250 \mathrm{ml}$ Erlenmeyer and incubated at $25^{\circ} \mathrm{C}$ on rotary shaker. For experiment, suspension in log-phase (3 days after subculturing) was used.

\section{Gene material}

Vectors containing the zinc transporters were kindly provided by Zeshan Hassan: vector BG0073 with kanamycin selection marker, containing Noccaea caerulescens ZNT1 coding sequence under control of $35 \mathrm{~S}$ promoter, and vector BG0014 with hygromycin selection marker, containing Noccaea caerulescens ZTP1 coding sequence under control of $35 \mathrm{~S}$ promoter. For positive control, vector $\mathrm{pKGW}$ with kanamycin selection marker, containing DsRed coding sequence under control of constitutive promoter, was kindly provided by Teun van Herpen.

\section{Agrobacterium for transformation}

Two lines of Agrobacterium tumefaciens Ag10 strain were transformed with BG0073 and BG0014 construct. Of each, single colony was picked and transferred to $100 \mathrm{ml}$ erlenmeyer flask containing $5 \mathrm{ml} \mathrm{LB}+$ antibiotics. Flask was incubated on shaker overnight at $28^{\circ} \mathrm{C}$. For pKGWDsRed, $5 \mathrm{ml} \mathrm{LB} \mathrm{+} \mathrm{antibiotics} \mathrm{culture} \mathrm{in} 50 \mathrm{ml}$ tube was inoculated with small drop of glycerol stock (taken with a toothpick). Tube was incubated on shaker overnight at $28^{\circ} \mathrm{C}$.

\section{Transformation of suspension cells}

Agrobacterium overnight cultures were spinned down and redissolved in 1-2 $\mathrm{ml}$ MS liquid medium (4.4 g/l MS+salts+vitamins, $30 \mathrm{~g} / 1$ sucrose, $0.2 \mathrm{mg} / \mathrm{l}$ 2,4 D, pH5.7 with $\mathrm{KOH}$ ). $40 \mathrm{ml} 3$ day old BY2 cell suspension culture was filtered using Whatmann filter, and cells were resuspended in same volume of MS liquid medium. $4 \mathrm{ml}$ of cells suspension was mixed with $100 \mu$ l agrobacterium culture and transferred to Petri dish with Whatmann filter paper on the bottom. Petri dishes were sealed with parafilm and incubated for 2 to 3 days at $28^{\circ} \mathrm{C}$ in the dark without shaking. After incubation filter papers were washed with $3 \times 10 \mathrm{ml}$ liquid $\mathrm{MS}+500 \mu \mathrm{g} / \mathrm{ml}$ Cefotaxim and transferred to selective plates containing MS agar + kanamycin or hygromycin ((4.4 g/l MS+salts+vitamins, $30 \mathrm{~g} / 1$ sucrose, $0.2 \mathrm{mg} / 1$ 2,4 D, pH5.7 with $\mathrm{KOH}, 8 \mathrm{~g} / \mathrm{l}$ agar, $50 \mu \mathrm{g} / \mathrm{ml}$ kanamycin or $20 \mu \mathrm{g} / \mathrm{ml}$ hygromycin). Washing liquid of all plates with same transformation vector (containing suspension cells) was collected in $50 \mathrm{ml}$ tube and cells were spinned down at $500 \mathrm{rpm}$ for $3 \mathrm{~min}$. Pellet was resuspended in $30 \mathrm{ml}$ liquid $\mathrm{MS}+500 \mu \mathrm{g} / \mathrm{ml}$ Cefotaxim, spinned down again and resuspended in $4 \mathrm{ml} /$ plate. Cells were transferred to selective plates containing washed Whatmann filter paper and spread out evenly over the filter paper. Plates were incubated for 6 days at $28^{\circ} \mathrm{C}$ in the dark.

\section{Growth of transformed cells on Zinc gradient}

After 6 days of selection on MS+kanamycin or hygromycin plates, filter papers were cut into two and transferred to selective plates (MS agar + antibiotics) containing different concentrations $(0,50,100,200,300$ or $500 \mu \mathrm{M})$ of zinc (see: table 1). Plates were incubated for two weeks at $28^{\circ} \mathrm{C}$ in the dark.

\section{Analysis of calli}

Calli were scored by the professional eye of Prof. Dr. Ir. P. Bijman under supervision of Rector Magnificus L. Woittiez. Plates were observed under a binocular and pictures were made with Nikon digital camera. DsRed positive controle plates were observed with fluorescence binocular, using DsRed bandpass filter. A small piece of filter paper was cut off and examined under Carl Zeiss fluorescence microscope. Additionally, cells were resuspended, put onto a microscope slide and analyzed.

\section{RESULTS \& DISCUSSION}

Callus growth was observed on only four plates, including both negative control plates and the non-selective plates of the BG0014 and BG0073 transformation. No callus was found on the positive control plates.

\section{No callus growth was observed on most of the plates}

Despite the acclaimed ease and success rate of BY2 suspension transformation (An, 1985), we observed little or no callus growth on any of the plates containing transformed BY2 cells. One possible explanation is that the incubation period was too short. Indeed, it could be that in a few more weeks, calli will start to develop. However, on the negative control plates (where no agrobacterium had been added) there was plenty of callus present, showing that the incubation period was certainly long enough for development of callus from healthy BY2 cells.

A second likely explanation is that in fact, there were no living transformed BY2 cells, and therefore the kanamycin or hygromycin inhibited callus growth in all nontransformed cells. Our methods were different from the protocol (Petrasek et al., 2003) in that we transformed the tobacco cells in a petri dish on top of a filter paper. Also, we did not try different concentrations of agrobacterium, but instead we used only one. Therefore, absence of living transformed cells can have two main reasons. First of all, it could be that all agrobacterium attached to the filter paper and therefore did not reach the BY2 cells. According to the Petrasek protocol, successful progression of the transformation is visible by a milky-white color of the 
medium during the co-incubation of tobacco and agrobacterium. We did not observe this; in our plates, the medium remained clear. This observation speaks for the explanation that transformation did not progress very well. Secondly, it may be that we had too many agrobacteria, leading to aggressive infection and death of the BY2 cells. Our observation that even on the plates without antibiotics, no or very little callus developed, speaks for this explanation. Apparently, the agrobacterium treatment somehow inhibits the development of those cells that were in touch with it; the only cells that were not in touch, the negative control cells, develop callus very abundantly.

\section{Negative control callus was growing on selective medium with kanamycin}

We observed some callus growth of the untransformed negative control cells on a selective plate containing kanamycin (Fig. 1). Callus growth was definitely not as abundant as on the plate without kanamycin, but still clearly visible by the naked eye. This result shows that kanamycin pressure was probably too low, either because a too low concentration was added or because the kanamycin was of bad quality (old). In fact, we used only half of the concentration that was recommended in the Petrasek protocol, so this could explain the escape of a large number of untransformed cells. Also, it could be that the high cell density allows some cells to live and proliferate on top of eacho ther, thus reducing the effect of the kanamycin in the medium.

\section{No red fluorescence was observed in the positive control}

As there was no callus in the negative control to analyze, we placed the complete plates under a fluorescence binocular. However, we did not observe any red fluorescence, indicating that there was no expression of the DsRed gene. Additionally, we analyzed the suspended cells and small pieces of filter paper with cells under a fluorescence microscope. In none of these samples, red fluorescence was observed, even though small cell clumps could be seen in the bright field image of the positive control plate without antibiotics. This shows that the cells are alive but are not forming callus (Fig. 2). Possibly, in a few more weeks still some callus will grow.

\section{No difference was observed between the different zinc concentrations}

As no callus at all was observed on any of the zinc gradient plates, naturally we did not observe a difference between the plates (Fig. 3). This makes discussion of these results rather trivial. However, also in this case, we hope that in a few weeks still some callus will develop.

\section{CONCLUSIONS}

It is concluded that maybe in a few more weeks, some callus would be observed, is not (necessarily) a wishful thinking since the protocol of Petrasek et al., 2013 describes that resistant colonies arise only three-four weeks after incubation on the selective plates. We have scored already after two-and-a-half weeks, and therefore it could very well be that it is simply too early to draw any conclusions; if in another two weeks we still do not observe any callus, than we can say that the transformation for some reason did not work, or that are cells for some reason do not proliferate. What we do know is that the starting material is healthy and that the medium composition is good; the abundant callus development on the negative control plate confirms this. Now, we can only wait to see if still some callus will develop on the other plates.

\section{ACKNOWLEDGEMENT}

We acknowledge the support of Corrie Hanhart for providing assistance in required materials.

\section{AUTHORS CONTRIBUTION}

Zeshan Hassan designed the experiment. Paul and Lotte performed the experiments and analyzed the data. Zeshan, Paul and Lotte and Jawad Munawar Shah wrote the manuscript.

\section{CONFLICT OF INTEREST}

The authors declare that there is no conflict of interest regarding publication of this article.

\section{REFERENCES}

[1] An, G., 1985. High Efficiency Transformation of Cultured Tobacco Cells. Plant Physiology, 79: 568-570.

[2] Assunção, A.G.L., Da CostaMartins, P., De Folter, S., Vooijs, R., Schat, H., Aarts, M.G.M., 2001. Elevated expression of metal transporter genes in three accessions of the metal hyperaccumulator Thlaspi caerulescens. Plant, Cell and Environment, 24 (2): 217-226.

[3] Desbrosses-Fonrouge, A.-G., Voigt, K., Schröder, A., Arrivault S., Thomine, S., Krämer, U., 2005. Arabidopsis thaliana MTP1 is a $\mathrm{Zn}$ transporter in the vacuolar membrane which mediates $\mathrm{Zn}$ detoxification and drives leaf $\mathrm{Zn}$ accumulation. FEBS Letters, 579 (19): 4165-4174.

[4] Dickinson, N.M., Baker, A.J.M., Doronila, A., Laidlaw, S., Reeves, R.D., 2009. Phytoremediation of inorganics: Realism and synergies. International Journal of Phytoremediation, 11 (2): 97-114.

[5] Grotz, N., Fox, T., Connolly, E., Park, W., Guerinot, M.L., Eide, D., 1998. Identification of a family of zinc transporter genes from Arabidopsis that respond to zinc deficiency. Proceedings of the National Academy of Sciences of the United States of America, 95 (12): 7220-7224.

[6] Hassan, Z., 2013: Functional analysis of zinc hyperaccumulation related genes of Noccaea (Thlaspi) caerulescens for phytoremediation purposes. $\mathrm{PhD}$ thesis, Wageningen University and Research Centre, Wageningen, The Netherlands. ISBN 97894-6173-430-3.

[7] Hassan, Z., Aarts M.G.M., 2011. Opportunities and feasibilities for biotechnological improvement of $\mathrm{Zn}, \mathrm{Cd}$ or Ni tolerance and accumulation in plants. Environmental and Experimental Botany. 72(1): 53-63.

[8] Lasat, M.M., Pence, N.S., Garvin, D.F., Ebbs, S.D., Kochian, L.V., 2000. Molecular physiology of zinc transport in the $\mathrm{Zn}$ hyperaccumulator Thlaspi caerulescens. Journal of Experimental Botany, 51 (342): 71-79.

[9] Nagata, T., 1987. Interaction of plant protoplast and liposome. Methods in Enzymolog, 148: 34-39.

[10] Nagaya, S., Nakai, Y., Kato, K.., Sekine, M., Yoshida, K.., Shinmyo, A., 2000. Isolation of growth-phase-specific promoters from cultured tobacco cells. Journal of Bioscience and Bioengineering, 89 (3): 231-235.

[11] Petrásek, J., Cerná, A., Schwarzerová, A., Elckner, M., Morris, D.A., Zazímalová, E., 2003. Do Phytotropins Inhibit Auxin Efflux by Impairing Vesicle Traffic? Plant Physiology, 131: 254263. 


\begin{tabular}{|l|l|l|l|l|}
\hline$[$ Zinc $](\mu \mathrm{M})$ & BG0014* & BG0073* & Positive control* & Negative control* \\
\hline 0 no antibiotic & $1 \times 1$ & $1 \times 1$ & $1 \times 1$ & $1 \times 1$ \\
\hline 0 & $1 \times 1$ & $1 \times 1$ & & $1 \times 1$ \\
\hline 0 & $1 \times 1$ & $1 \times 1$ & & \\
\hline 0 & $2 \times 1 / 2$ & $2 \times 1 / 2$ & $1 \times 1 / 2$ & \\
\hline 50 & $2 \times 1 / 2$ & $2 \times x^{1 / 2}$ & $1 \times 1 / 2$ & \\
\hline 100 & $2 \times 1 / 2$ & $2 \times 1 / 2$ & $1 \times 1 / 2$ & \\
\hline 200 & $2 \times 1 / 2$ & $2 \times 1 / 2$ & $1 \times 1 / 2$ & \\
\hline 300 & $2 \times 1 / 2$ & $1 \times x^{1 / 2}$ & \\
\hline 500 & $2 \times 1 / 2$ & $1 \times x^{1 / 2}$ & \\
\hline
\end{tabular}

Table 1: Experimental set-up. In total, four transformations were done: two different zinc-transporters (BG0014 with hygromycin selection marker and BG0073 with kanamycin selection marker), one positive control (DsRed with kanamycin selection marker) and one negative control (no transformation). For each transformation, one batch of cells was plated on MS plate without antibiotics. In total, four positive control transformations, 2 negative control transformations and two times nine zinc transporter transformations were carried out and put on plates with filter paper. After 6 days on selective plates, the filter papers were cut in half and transferred to zinc selective plates. * in $\mathrm{nr}$ of plates $\mathrm{x}$ nr of filter papers

\begin{tabular}{|l|l|l|l|l|}
\hline$[$ Zinc $](\mu \mathrm{M})$ & GB0014* & GB0073* & Positive control* & Negative control* \\
\hline 0 no antibiotic & A little bit of callus & A lot of callus & None & A lot of callus \\
\hline 0 & None & None & & Some callus \\
\hline 0 & None & None & & \\
\hline 0 & None & None & None & \\
\hline 50 & None & None & None & \\
\hline 100 & None & None & None & \\
\hline 200 & None & None & None & \\
\hline 300 & None & None & None & \\
\hline 500 & None & None & None & \\
\hline
\end{tabular}

Table 2: Callus growth on control plates with and without antibiotics and on zinc gradient plates. No callus growth was observed on the zinc gradient plates and on most of the

selective plates, apart from the negative control selective plate which showed some callus growth.

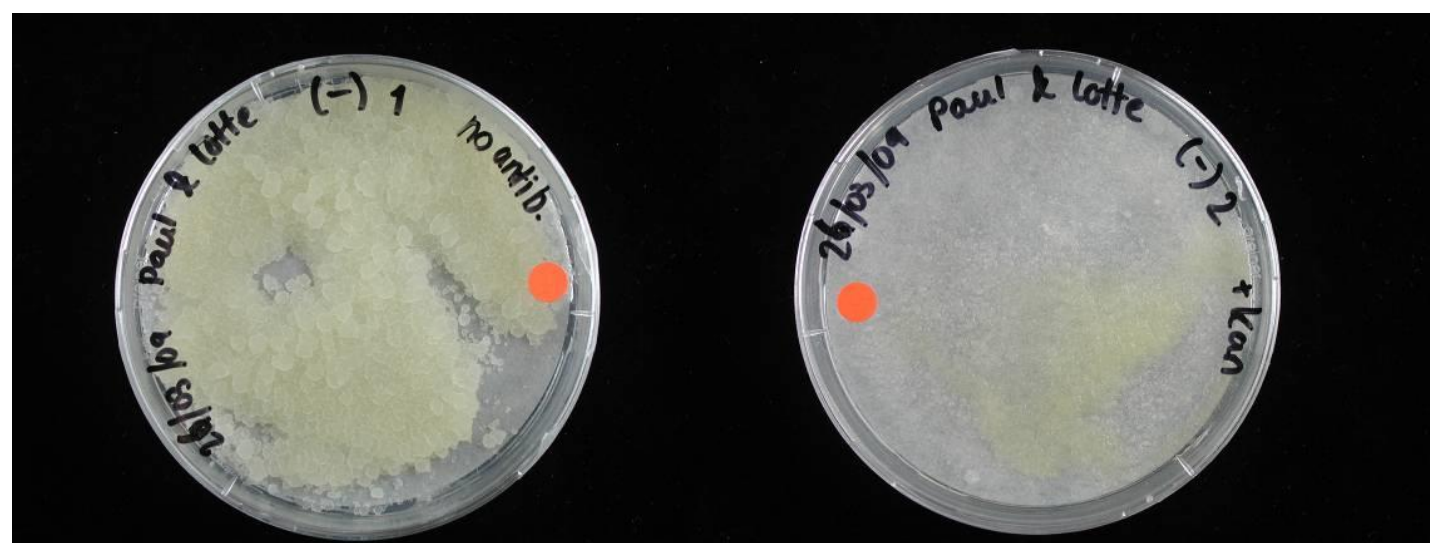

Figure 1: Negative control plates with callus. Left: no antibiotic was applied and a lot of callus growth was observed. Right: on negative control plate with kanamycin-containing medium also some callus growth was observed.

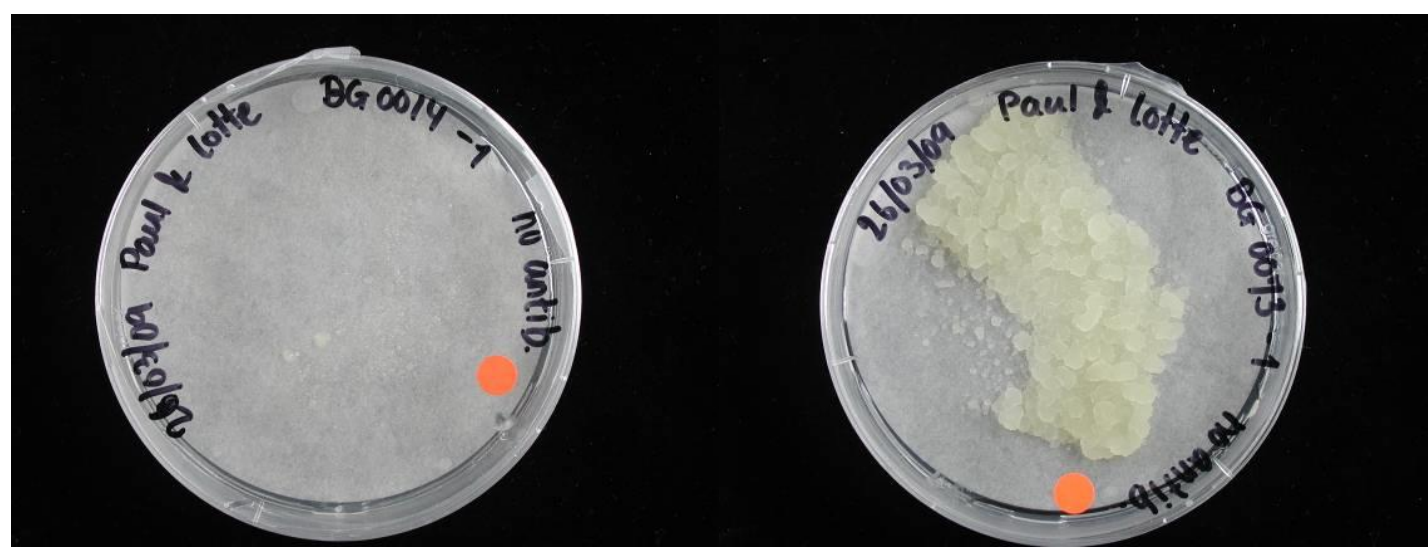

Figure 2: Transformed cells without antibiotic selection medium. Left: BG0014 shows a little bit of callus formation. Right: BG0073 shows a lot of callus formation. 


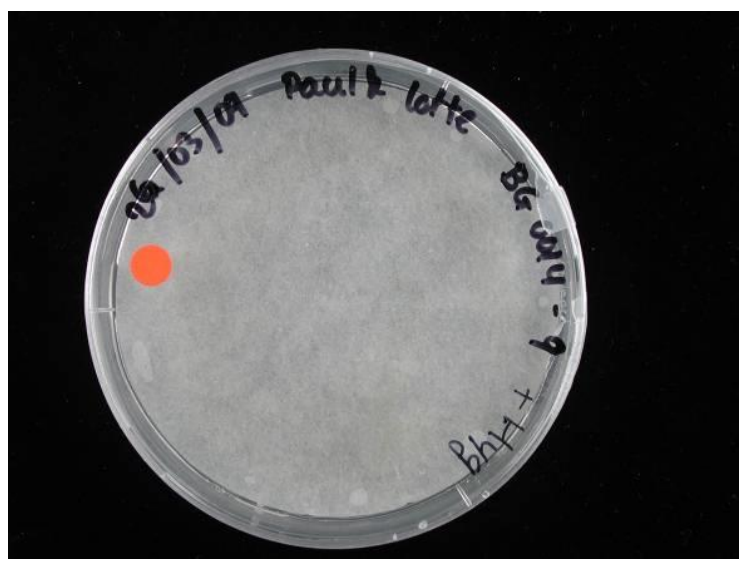

Figure 3: Example plate selective medium with or without zinc gradient. For BG0014 on selective medium, no callus growth was observed. The plates of the Zinc gradient also showed no callus formation. 